\title{
Reconstruction of Integrated Legal System for Protecting the Victims of Domestic Violencein Divorce Cases
}

\author{
Naqiyah $^{1 *}$, and Nita Triana ${ }^{2}$ \\ ${ }^{1}$ Faculty of Ushuluddin, Adab, and Humaniora, Purwokerto State of Islamic Institute, Purwokerto \\ Central Java Indonesia \\ ${ }^{2}$ Faculty of Syariah and Law, Purwokerto State of Islamic Institute, Purwokerto Central Java \\ Indonesia
}

\begin{abstract}
There is a guarantee for legal protection for all citizens without any discrimination. However, there are many cases of victims of domestic violence, hidden in civil law cases that are handled by religious courts. It is because the religious courts do not have authority to handle criminal cases. This paper aims to examine the feasibility of reconstructing the existing integrated legal system in protecting the victims of domestic violence in divorce cases in Cilacap District. Furthermore, this study is to research a model of an integrated legal system of the protection of victims of domestic violence in divorce cases. This research is a non-doctrinal legal research with socio-legal approach using a qualitative derived from literature and a survey method. The method used was observation, depth interview, document interpretation. The data were taken from Religious Court, police, and community leaders in Cilacap. The data were analysed by the theory of legal work. This research concludes that one of the solutions for the protection of victims of domestic violence in divorce cases is to reconstruct an integrated legal system model from all its elements that include legal structure, substance and culture so that it can handle the cases of domestic violence effectively. .
\end{abstract}

\section{Introduction and literature review}

Although all Indonesian are legally protected as stated in article 28D (1) of the Indonesian 1945 Constitution, the "Anti Domestic Violence Law", but, there are still many cases of domestic violence against women. The National Commission on Women in its annual record in 2017, revealed that there are 259,150 cases of violence against women, 245,548 cases are handled by 359 Religious Courts which led to divorce, the remaining 13,602 cases are in service-providing institutions that acted as partners in 34 provinces.[1] These authors also report that the violence against wives is at the highest rank $(245,548,10,205$ cases $)$ from the service provider partners, and 903 cases from data reported directly to the women's commission.[1]

\footnotetext{
* Corresponding author : naqiyah.mukhtar@iainpurwokerto.ac.id.
} 
Sulistyowati and Antonius state that it is difficult to find cases with violence background, because these are hidden in the civil cases.[2] Then, Zulfatun Nikmah concludes that Law No. 20 of 2003 could not be effectively enforced to protect the victims of domestic violence.[3] Naqiyah and Nita Triana conclude that the divorce resolution through the mediation model that is integrated into the Religious Courts does not achieve the expected results due to several factors: cases, mediators, parties, supporters, and non-standard mediation rooms.[4] Furthermore, Nita Triana et al. finds an integrated model that may be the most ideal in an Indonesian cultural context. This model is integrated into the procedural law in the religious courts by involving respected, trusted community leaders, scholars, senior citizens, and certified mediators.[5] Then, Tri Lisiani et al, states that judges tend to use formal regulations in accordance with the law and lack of innovations in solving divorce cases.[6]

\subsection{Legal protection for women domestic violence}

Protection is any effort that aimed at providing a sense of security to a victim carried out by the family, lawyers, social institutions, police, prosecutors, courts, or other parties both temporarily and based on a court verdict (Article 1 (4) of Protection of victims of domestic violence Law number 23 of 2004.

\subsection{Legal Work Theory}

According to L. Friedman ( 1975 ) the Legal System consists of: a. Legal Structures in the forms of institutions that are created by the legal system, b. Legal Substance, that is the actual results issued by the legal system in the form of legal norms, c. Culture or legal culture, in the form of ideas, attitudes, hopes and opinions about the law.[7] In addition, Satjipto then explains that the three parts of the legal system are as follows: 1). The legal structure is likened to a machine; 2). Legal substance is what the machine does and produces; 3). Legal culture is anything or anyone who decides to turn on and turn off the machine, and decide how the machine is used.[8] In the context of protection for victims of domestic violence in divorce cases, the legal structures are state institutions such as the police, religious courts, and women's protection organizations. Whereas, the legal substances are various regulations concerning the settlement of domestic violence conflicts, the Religion Court Procedure Law, the Marriage Law, and the Compiled Islamic Law. The culture is the internal legal culture and behaviour of the actors from the police, judges, and employees within the Religious Court in addition to the culture and behaviour of the Community (external legal culture).

The work of the legal system in society according to the theory of Chambliss and Seidman involves several elements: law-making institution, sanction activity institution, role occupant, societal personal force, legal culture, and feedback from the process of running the current law. [9] The model of the operation of law in society is presented in Fig.1 


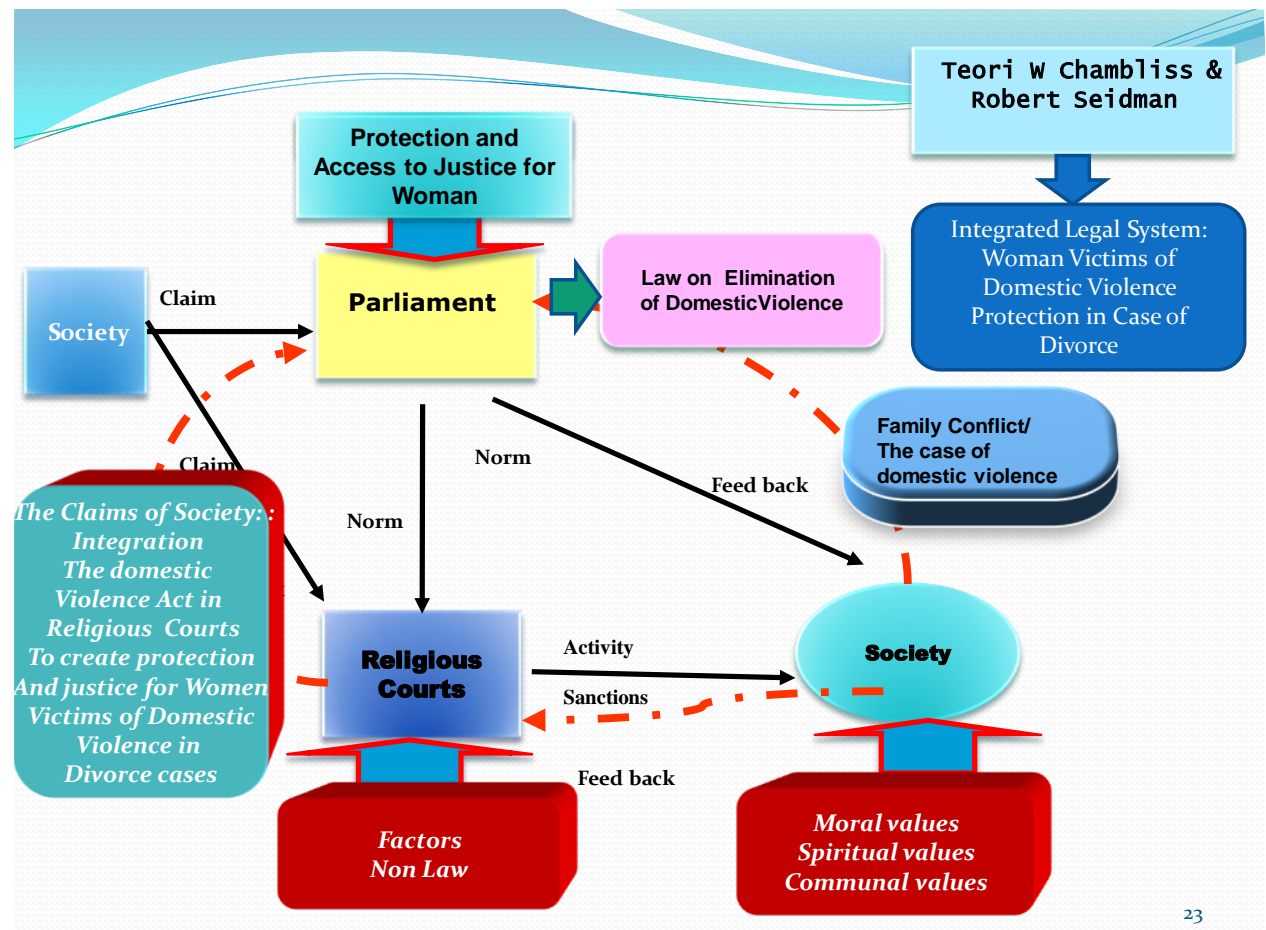

In this demonstration, every legal system influences, encourages or forces the legislation and state power institutions. This will lead various groups within the community to sue to the regulatory/legal institutions, (the Parliament and Government). Then, by the power of the state that carry this out by using law as the way to encourage or to enforce the desired behaviours of the community as the role holder. The law enforcement is carried out by providing sanctions by the sanctioning institutions, in this case, the Police and the Religious Courts. Then there is the response of the role holder (community) to the claims and pressures directed at him, in the form of compliance or feedback, objections, proposals, and so on. Furthermore, social and personal forces influence the behaviours of the role holders and institutions. Social forces can be in the form of environmental influences such as economics, culture, and others.

The theory of the operation of law from Seidman is very useful for building the construction of an integrated legal system, from various aspects, that is from the culture of society, institutional culture, institutional structure of law enforcement and how they together influence each other in the operation of law.

\section{Objective of the study}

This paper aims to examine the feasibility of reconstructing the existing integrated legal system (including the religious courts, police, and community) in protecting the victims of domestic violence in divorce cases in Cilacap District. Furthermore, this study is to research a model of an integrated legal system of the protection of victims of domestic violence in divorce cases. 


\section{Methods}

This is a non-doctrinal legal research with socio-legal approach using a qualitative derived from literature, observation, depth interview, and document interpretation. The data were taken from Religious Court, police, and community leaders in Cilacap district. The data were analysed by the legal work theory.

\section{Discussion}

\subsection{Existing construction of protection of women victims of domestic violence in divorce cases}

Normatively, the protection of victims of domestic violence has been clearly stated in Law No.23 of 2004, namely: preventive stage, curative stage, and repressive stages to domestic violence perpetrators.[10] In reality, victims of domestic violence are commonly reluctant to come to the police and or district court to sue the criminals because of the lengthy process, expensive, and in some cases, the perpetrator is the relative. Therefore, the safest and fastest way to be taken by the victims is to come to court and sue for divorce.

In Cilacap Religious Court, divorce claims are the most common cases, therefore, there is great hope for judges to protect victims of domestic violence. Judges' efforts in these cases are as follows: when the case is processed in a religious court, the parties get mediation. Nevertheless, in reality, mediation in those cases rarely succeeds. To protect victims, judges do a variety of ways. They see the conditions of the victims in the trial. For victims who have long suffered from violence and the judge views that it cannot be reconciled, the trial process is accelerated by granting the sue and hastening decisions, so that the victims are immediately freed from the violence. However, for new victims and the judge sees it is possible to be reconciled, and then the advice is given. As the trial process is slowed down, in order to cool down and then peace is offered. In another form, the judge gives the verdicts of the case by referring to Law Number 23 of 2004 of anti-domestic violence, which the victim can use it if she will proceed the case to the district court.

In addition, the judge's verdicts give compensations to satisfy the parties depend on the conditions. Sometimes, the judge's verdict obliges the husband to foster the kids (hadlanah). In certain conditions, the husband is not allowed to live in the same house with his victim. The judges sometimes use their ex-officio rights beyond on the existing rules (a progressive decision). Occasionally the judge provides counselling, involves the families of both parties, and even sometimes involves the local government.[11]

In handling cases of victims of domestic violence, the police maximize mediation by trained woman police officers as mediators, and in most cases, reconciliation can be reached, although sometimes the police need to cooperate with social services called Citra (Cilacap without violence).[12] The success of the police in mediating these may be due to the fact that the parties are in a state of under pressure. These are in contrast to those handled by the religious court. Furthermore, according to the members of the Cilacap Regional People's Legislative Assembly, such as Winarto[13] and Zaeni[14] the most important is preventive steps, besides counselling, mentoring, and cooperation from various sectors such as the courts, police, and government agencies.

According to several community leaders such as the Cilacap Indonesian Ulema Council to protect the victims is to see the case, the most important thing is to prioritize the benefit of victims and their families. It needs to be started through non-litigation channels such as advice, counselling, by involving the family, respected figures, and professionals. If this way fails, the litigation line will be taken.[15] 


\subsection{Weaknesses in the construction of protection of domestic violence victims in divorce cases.}

Among the weaknesses of protection of domestic violence victims have existed in all elements of the legal system. In the structure, the limited quantity and quality of mediators are in religious courts so that they do not maximally mediate the victims, also the minimum number (21) of judges who handle 7000 cases in a year. Then, on the law substance is the limited authority of religious courts that serve merely civil cases, the procedure for making court proceedings in the police, which is not easy to make records of domestic violence victims. Furthermore, in legal culture, cases of domestic violence are perceived as private cases which should be kept as hidden as possible, because opening them to the public sphere is considered dishonour. Besides, the victims are economically dependency on the offender so that it needs to consider carefully taking litigation path.

The results of the analysis the above data using the theory of Robert Seidman are as follows:

Law-making institution, in this case, the People's Representative Council has regulated the protection of victims of domestic violence with Act No. 23 of 2004. Even the Cilacap District government has been concerned about protecting victims of domestic violence by creating a special institution called Citra (Cilacap without violence). This is conducted for the benefit of the community. In reality, most victims choose to report their cases to a religious court that is not authorized to handle domestic violence so that the criminal element of domestic violence hidden in the divorce cannot be resolved. In fact, when the case is proposed to the police as an institution for implementing sanctions, the problem could be relatively resolved.

The victims of domestic violence generally sue their cases in religious courts because they are generally reluctant to report to the mandates. They have a perception that domestic violence is private and embarrassing cases that must be kept confidential. Other considerations are economic dependency of victims on the doers, the psychological issues of their children if their father deals with the police, maintaining social relations, especially if the perpetrator is their family member. Therefore, the victims tend to choose to compromise even though they have to suffer and to get divorced status to be free from domestic violence. These are the reasons why the offenders are free from punishment as stipulated in Law no. 23 of 2004.

Thus, it seems that personal and societal force and legal culture that live in the community are still very strong. There is a strong assumption in the community that the judicial institutions including the Religious Courts especially in divorce cases are the right places to judge whether or not a person is wrong or right (win-lose). They are not the right places for deliberations and consensus to win. This is in line with Daniel S. Lev's research, as quoted by Raharjo,[8] that the culture of Indonesian society emphasizes communal solidarity and avoids conflict. Lev also, states that the mediation/conciliation would be a permanent characteristic in Indonesian legal culture.[16] This is in accordance with a mirror thesis by Brian Z Tamanaha that law is always limited to certain communities because law is a reflection of ideas, traditions, values, and goals of society. 


\subsection{Reconstruction of an integrated legal system for protecting women victims of domestic violence}

One of the various weaknesses in the existing legal protection of victims of domestic violence, in terms of legal structure, we offer a model of an integrated legal system for a reconstruction. The Religious Court is a strategic institution in the protection of the victims of domestic violence. The number of judges need to be reconsidered to be rational to the number of divorce cases. The unbalanced number of judges affects the legal reasoning and verdicts of the judges. Progressive Judges are needed in the legal reasoning and decisions that are sufficiently impartial and care for the victims of domestic violence. Courageous legal breakthroughs, such as adequate compensation in the form of Mut'ah, counseling for husbands and bold decisions that say there has been domestic violence for the purpose of further examination in the District Court. The police institution is also an important legal structure that has a strategic position. Mediation, which is the mediator of the Police, has a considerable opportunity for psychological sanctions against the perpetrators. Integration and Collaboration from the Religious and Police Courts in terms of mediation will greatly help to suppress divorce and domestic violence. Police officers will be very good to be given the opportunity to become mediators in the Religious Court.

Another important Legal structure is the community organizations that must exist in each region and are ready to continuously provide protection and awareness as well as the courage to report domestic violence cases. In terms of legal culture, it is necessary to value that husband and wife and other family members have rights and obligations that must be respected by one another, there is no superiority and inferiority. The legal culture that holds that domestic affairs are private, so domestic violence is also private, so it does not need to be reported, it must be reconstructed immediately. The change of thinking paradigm must be the duty of religious leaders and organizations concerned with family protection.

Substantially, regional regulations to protect the victims are required to reconstruct the orientation of the existing legal system from preventive to repressive. On the other hand, in terms of national regulations, it is very urgent to make a law that can deal with domestic violence in an integrated manner.

\section{Conclusion}

The legal system that is currently available to protect victims of domestic violence has not been strictly implemented. This may be due to several issues that exist in the Indonesian legal system. From the legal-structural point of view, the quality and number of judges in religious courts need improvement. In addition, culturally, people still consider that domestic-violence cases are private affairs. Furthermore, substantially, the scope of authority of the religious courts is still limited to the resolution of divorce cases so that they cannot respond to cases of domestic violence. For these reasons, new strategies including improving the progressiveness and quantity of judges, raising public awareness that domestic violences are public matters, and enhancing the authority of religious courts to protect domesticviolence victims are required to solve these issues.

\section{References}


[3] Z. Ni'mah, "Effectiveness of Law Enforcement Elimination of Domestic Violence," Mimb. Huk., vol. 24, pp. 1-84, 2012.

[4] Naqiyah and N. T. Naqiyah, "Rekonstruksi Model Penyelesaian Kasus Perceraian Melalui Mediasi yang Diintegrasikan Pada Pengadilan Agama Purwokerto," Purwokerto, 2011.

[5] N. Triana, N. Naqiyah, Marwadi, and Y. S. Safrani, "Rekonstruksi Model Mediasi yang Diintegrasikan Pada Hukum Acara Pengadilan Agama Perspektif Para Pihak (Studi Socio-Legal Mediasi di Pengadilan Agama Se Eks Karesidenan Banyumas)," Purwokerto, 2014.

[6] H. Tri Lisiani, N. Naqiyah, and N. Triana, "Interpretation of the judges of the Concept of Substantive Justicein the Case of Divorce in Religious Courts and State Courts Through out the Formerresidency of Banyumas," Purwokerto.

[7] L. Friedmann, The Legal System: A Social Science Perspective. New York: Russell Sage Foundation, 1975.

[8] S. Rahardjo, Hukum Progresif Sebuah Sintesa Hukum Indonesia. Yogyakarta: Genta Publishing, 2009.

[9] W. J. C. and R. B. Seidman, Law, Power and Order. Massachusett: AditionPublishing Company Wesley Reading, 1972.

[10] DPR, Undang-Undang Republik Indonesia Nomor 23 Tahun 2004 Tentang Penghapusan Kekerasan Dalam Rumah Tangga. Republik Indonesia: Lembaran Negara Republik Indonesia Tahun 2004 Nomor 4419, 2004.

[11] M. Tobri, "Interview with judges at the Religious Court." .

[12] Iptu Johan Widodo, "Interview with Cilacap District Police Chief." Cilacap.

[13] W. (Gerindra Party), "Interview with members of the regional legislative assembly." Cilacap.

[14] Z. (National A. Party), "Interview with members of the regional legislative assembly." .

[15] H. Nasrullah, "Interview with Cilacap Indonesian Ulema Council." Cilacap.

[16] D. S. Lev, Judicial Institutions and Legal Culture in Indonesia”, in Culture and Politics in Indonesia. Cornell University Press, 1972. 